\title{
PRACTICAL ASPECTS OF RISK ACCEPTANCE CRITERIA DEVELOPMENT IN MARITIME SHIPPING PRAKTYCZNE ASPEKTY OKREŚLANIA KRYTERIÓW
AKCEPTOWALNOŚCI RYZYKA W ŻEGLUDZE
MORSKIEJ
}

\author{
Teresa Abramowicz-Gerigk, Zbigniew Burciu, Piotr Kaminski \\ Gdynia Maritime University \\ e-mail: tagerigk@am.gdynia.pl; zbj@am.gdynia.pl;pkaminski@am.klif.gdynia.pl
}

\begin{abstract}
The paper presents practical aspects of development of acceptable risk levels in maritime shipping with respect to the cooperation of parties involved in maritime safety, commonly used risk acceptance principles, criteria and uncertainties related to their development. The results of analysis of risk assessment methods used for potentially hazardous operations on board ships performed on the basis of extensive studies on the onboard safety management systems is presented. The merits and drawbacks of the approach used in the development of risk acceptance criteria in onboard safety management systems are discussed.
\end{abstract}

Keywords: maritime shipping, safety, risk acceptance criteria

Streszczenie: $W$ artykule przedstawiono praktyczne aspekty wyznaczania dopuszczalnego poziomu ryzyka $w$ żegludze morskiej, $w$ odniesieniu do wzajemnych zależności stron zaangażowanych $w$ obszarze bezpieczeństwa morskiego, ogólnie stosowanych zasad i kryteriów akceptowalności ryzyka oraz niepewności zwiazanych z określaniem kryteriów akceptowalności. Na podstawie obszernych badań pokładowych systemów zarzązania bezpieczeństwem statku przeprowadzono analize metod oceny ryzyka operacji stwarzajacych potencjalne zagrożenie dla statku i załogi. Omówiono wady i zalety podejścia stosowanego obecnie przy opracowywaniu kryteriów akceptowalności ryzyka w pokładowych systemach zarządzania bezpieczeństwem.

Słowa kluczowe: żegluga morska, bezpieczeństwo, kryteria akceptowalności ryzyka 


\section{Introduction}

The rate of accidents in maritime shipping and scale of harm have an immediate influence on the organizational and legislative actions to enhance maritime safety. This results in risk assessment being a primary function of the strategic safety management.

The minimization of risk obtained due to the legislation and political pressure has the influence on the infrastructure, operations and processes in maritime transport. The possible actions should be done to remove all risks, however considering limited resources and practical or physical possibility to remove all risks the level of acceptable risk is defined by the acceptance criteria. The monitoring of risk level changes is also carried out with respect to risk acceptance criteria. New hazards that may have been inadvertently created through a risk response due to the introduction of new technology and equipment, new work practices or procedures, changes within the work environment and introduction of new staff with different experience and competencies must be considered [3].

The remaining risk or residual risk is the risk that remains after the relevant measures are introduced [16]. The most important problem is balancing risks and benefits.

Risk should be accepted with respect to current values of society and in the enterprise. The current risk parameters, indices and results which have the significant influence on the risk level must be identified $[1,10,13]$. There is the qualitative, semi quantitative and quantitative risk acceptance criteria applied [5,6,8,9].

Since 1997 when International Maritime Organization (IMO) has adopted Formal Safety Assessment Guidelines (FSA), works on the generally accepted risk evaluation criteria used in three steps of FSA: in Step 1 to identify hazards, in Step 4 to present cost effectiveness of risk control options and in Step 5 to formulate recommendations are still carried out.

The determination the risk level in maritime shipping is based on rules as well as on the best maritime practice - intellect, knowledge, experience and responsibility of the ship master, crew and shore personnel [2]. On the selected stages of ship operation, as for example navigation along the port approach waters and inside harbour docks, the simultaneous conformation to the rules and good maritime practice involves the collaboration of Ship Master, maritime pilot, tug boat masters and Vessel Traffic Services Operator or Harbour Master's Duty Maritime Officer. The requirements included in Polish Maritime Code obligate the Ship Master "to do his best before and during the voyage with respect to the vessel's capability to sail and in particular with respect to vessel's compliance with the safety requirements of both the rules and good maritime practice" [12].

There is a strong influence of political issues on the process of generally adopted risk evaluation criteria development which concerns the cooperation and correlation of different international parties involved in maritime safety and works of IMO. 


\section{Cooperation and correlation of parties involved in safety of maritime shipping.}

There are several universal definitions used to define safety at sea: freedom from danger, freedom from unacceptable risks and personal harm or not suffering losses [6]. Maritime safety includes safety and health of people, safety of the vessel and environment. Safety in maritime transportation includes safety of life at sea, safety of the vessel, safety at sea (war, piracy), safety of elements of shore infrastructure, safety of ship equipment and selected aspects of environment protection [2].

Merchant ship operation is a realisation of transportation process - passengers and goods shipping to generate income [8]. The safety of ship operation is dependent on the following factors:

- human factor,

- area of navigation,

- hydrometeorological conditions,

- ship technical condition,

- loading condition,

- reloading technology.

The creation of conditions for the implementation of the possibly highest safety standards in the world is the main aim of the policy of IMO. This policy requires the involvement of many parties - governmental institutions and companies.

The cooperation and dependence of the parties in the area of maritime shipping is presented in figure 1 .

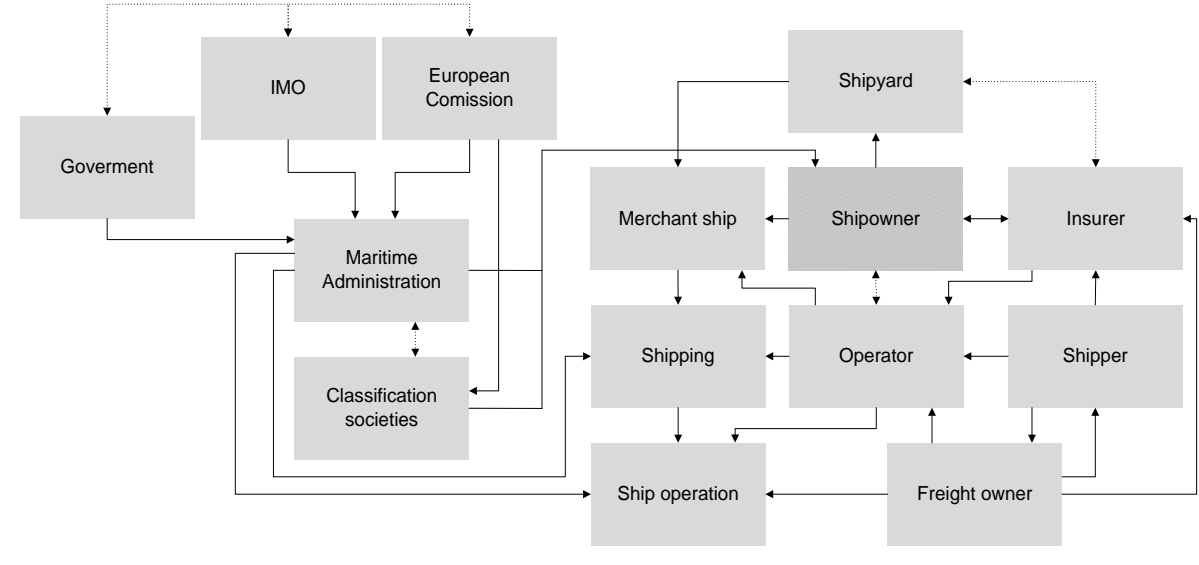

\footnotetext{
The Shipowner is the legal concept used in several countries only . In genera
only the ship operator should be used in the presented cooperation and dependence scheme.
}

Fig. 1 Cooperation and dependence of the parties in the area of maritime shipping [3, 8]. 
Practical aspects of risk acceptance criteria development Praktyczne aspekty określania kryteriów akceptacji ryzyka

\section{Risk acceptance criteria in maritime shipping,}

The commonly used principles for risk acceptance are as follows: ALARP (As low as reasonably practicable), established by the UK Health and Safety Executive (HSE), SFAIRP (So far as is reasonably practicable), which for all practical purposes is the same as ALARP), ALARA (As low as reasonably achievable) similar to ALARP, but usually referred to a situation where no "lower limit" (negligible risk) is defined.

Satisfying upper limit in form of risk criteria is from a decision making point of view a different approach compared to an ALARP evaluation.

ALARP introduces the concept of three different "risk zones": unacceptable region - risk is too high to be acceptable and risk reducing measures must be introduced, ALARP zone - risk is below the unacceptable level, but is not acceptable without considering further measures to reduce risk and acceptable region - risk is acceptable and no further measures are considered necessary.

ALARP evaluation represents a more complex decision making situation, requiring more involvement from managers and technical/professional disciplines in order to find an optimum solution, taking into consideration economical, time and safety issues as well as constraints [7]. This principle is normally applied together with a limit for intolerable risk and a limit for negligible risk. The interval between them is the ALARP region [16].

Risk criteria within IMO are often formulated in the form of F-N diagram where the risk criteria limits the combination of the cumulative frequency $(F)$ and number of persons harmed $(\mathrm{N})$.

Maximum acceptable individual risk is $10^{-3}$ per year, negligible risk is $10^{-5}$ per year. For the risks in the ALARP domain for the events where 100 people are expected to be killed every 10000 years, the effectiveness of safety measures should be considered along with the financial criteria.

IMO and IACS (International Organisation of Classification Societies) propose to apply new risk reduction measures, if the resultant cost of a new measure is less than three million USD per potential life saved [15].

For the risk in the non-acceptable domain, for example an activity were 10 persons is expected to be killed every 100 years, the risk must be reduced at all costs [15].

Risk acceptance criteria as upper limits of acceptable risks have been used for offshore activities for more than 20 years. An example of typical risk acceptance criteria used is that the FAR value (expected number of fatalities per 100 million exposed hours) should be less than 10 for all personnel on the installation. The individual probability that a person is killed in an accident during one year should not exceed $0.1 \%$.

Recently there has been a discussion about the suitability of risk acceptance criteria to assess and control risks, whether the cost-effectiveness should be used rather than adoption of predefined risk acceptance limits [16]. 
The risk acceptance criteria play an active role in the risk assessment processes in Norwegian transport industry. In the United Kingdom ALARP principle is preferably used [7].

The value of prevented fatality (VPF) in maritime transport in Norway has been calculated to approximately 4 million USD, the commonly accepted values are between 1 and 15 million USD, offshore industry indicates a VPF equal to 3-15 million USD [14]

Environmental risk evaluation criteria address both global environmental risk and per ship environmental risks: based on a direct assessment of the risk to the environment from shipping at the global level as for example $\mathrm{CO}_{2}$ emissions and based on the risk to the environment on a statistical per ship basis - as fuel spills.

There is a broad equivalence between safety and environmental risks with the same risk index allowing for ranking of risks on a combined safety and environmental basis. For a given value of risk index, the safety harm VPF equal to 3 milon USD is the same as the environmental harm comprising environmental cost and clean-up cost.

\section{Uncertainties in the development of risk acceptance criteria in maritime shipping.}

Assuming the risk level in ship operation is a function of ship parameters for a particular operation [4], allows conducting risk assessment on the basis of certain risk acceptance criteria. The difficulties in the determination of risk acceptance criteria are related to the uncertainties following from the assumptions and simplifications.

The high level of uncertainty can be identified for the following hazards:

- exceedance of the safe age of the vessel,

- convenient flag vessel entity,

- vessel entry into the area of piracy.

Safe age of a vessel cannot be determined on the general basis. The types of vessel, operational conditions and maintenance policy have the strong influence on vessel's condition.

The technical reasons which are about $20 \%$ of all sea accidents are closely related to changes of the vessel's flag to the flag of convenience (cheap flag). Flag State Duties - the $94^{\text {th }}$ Paragraph of United Nations Convention on the Law of the Sea gives very high requirements in jurisdiction, technical and social administration control over the vessels entitled to the flag of the country. The procedure of changing the vessels flag can decrease the ship registration costs about 30\%-50\%. The failures and contribution in sea accidents of vessels entitled to the cheap flags in comparison to the OECD states flags are a few times greater.

The hazards related to the ship entry into the High Risk Areas (areas of piracy) are still the serious problem. Pirates attack one per 10 vessels transiting African shipping routes. Prior to transiting the High Risk Area, ship operators and Ship Masters carry out a thorough ship and voyage specific risk assessment to assess the 
Practical aspects of risk acceptance criteria development Praktyczne aspekty określania kryteriów akceptacji ryzyka

likelihood and consequences of attacks, based on the latest available information. The output of this risk assessment should identify measures for prevention, mitigation and recovery, which combines statutory regulations with supplementary measures to combat piracy [4].

The piracy methods are changing constantly. The practice shows that in most cases the crew is not able to guard the vessel. To overcome this problem the interim guidance to private maritime security companies (PMSCs) was agreed within IMO's $90^{\text {th }}$ session of Maritime Safety Committee (MSC) in May 2012.

A special high-level maritime security working group of the MSC agreed that the International Organization for Standardization (ISO) would develop new international standards for the assessment of PMSCs.

\section{Risk acceptance criteria used in safety management systems on board ships.}

The formalisation of the operational procedures for the hazardous operations for ship and crew allows for the interchangeable determination of risk level.

Safety management onboard ships is directly related to the acceptable risk value. It is based on the International Management Code for the Safe Operation of Ships and for Pollution Prevention (ISM Code), included in Chapter IX of International Convention for the Safety of Life at Sea (SOLAS) "Management for the Safe Operation of Ships".

This code has been accepted as a tool promoting international standards for the safe management and operation of ships and for pollution prevention, encouraging the development of safety culture in shipping [11]. ISM Code requires that ship operators establish the safety objectives and in addition develop, implement and maintain Safety Management System (SMS) on board all the ships they operate.

The analysis of safety management systems presented below is based on the study of the Safety Management System Manuals, circulars and specific instructions implemented onboard over 100 vessels, issued by operators of the following shipowners: Grimaldi Group - Italy (operator V-Ship, vessels entitled to the flag of Gibraltar), Stamco - Greece (vessels entitled to the flag of Bahamas), Stena Line Sweden (vessels entitled to the flag of Bahamas). The codes have been approved by Maritime Administrations and Classification Societies.

Risk assessment on board ships is carried out by Risk Assessment Team - Ship Master, Chief Engineer and Chief Officer on the basis of the documents defined in SMS:

- safety procedures manuals,

- instructions,

- check lists,

- risk assessment matrix.

All the manuals contain the similar procedures and check lists. The instructions are tailored to the type of vessel. In the selected aspects where the ISM code defines rules very precisely the check lists are identical in all systems. 
The measures of a safety levels in SMS systems onboard vessels are defined as risks of unexpected and unplanned events, which may occur during ship operation. Risk assessment is conducted using the risk matrix with five levels of likelihood and severity. ALARP and SFARP risk acceptance principles are used.

The risk ranges are defined as follows:

- acceptable (1-4)

- tolerable (5-12)

- intolerable (15-25).

The maximum acceptable risk level, defined as a product of likelihood and severity of harm is 4 . The risk matrix applied in onboard safety management systems is presented in Table 1.

Table 1. Risk matrix applied in onboard safety management systems

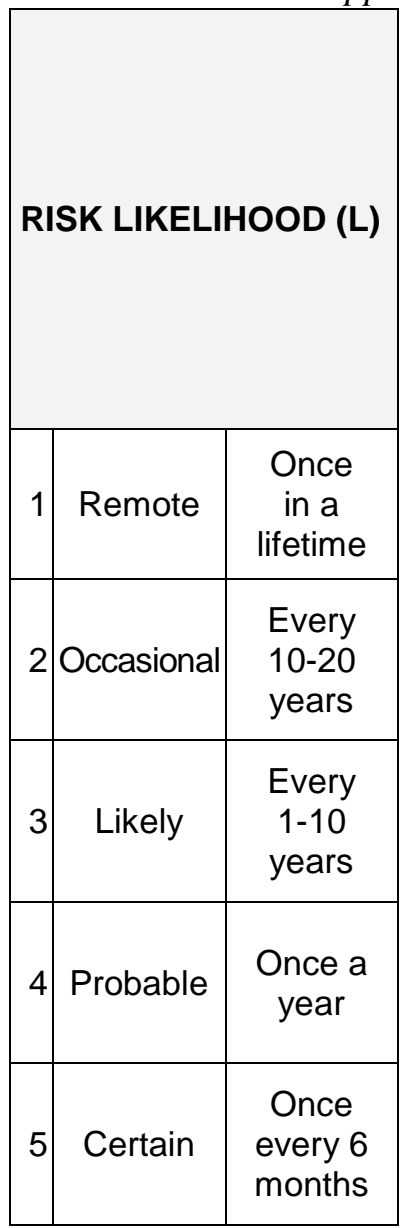

\begin{tabular}{|c|c|c|c|c|}
\hline \multicolumn{5}{|c|}{ RISK SEVERITY (S) } \\
\hline & & 売 & 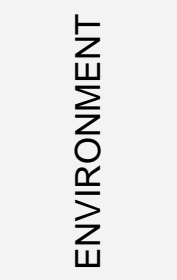 & 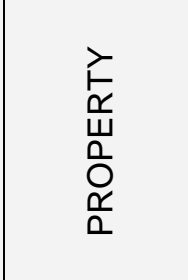 \\
\hline 1 & Negligible & $\begin{array}{l}\text { Minor injury } \\
\text { not requiring } \\
\text { first aid }\end{array}$ & $\begin{array}{l}\text { Less than } \\
10 \text { Itrs }\end{array}$ & $\begin{array}{l}\text { Less than } \\
\$ 10,000\end{array}$ \\
\hline 2 & Minor & $\begin{array}{c}\text { Minor injury } \\
\text { requiring } \\
\text { first aid } \\
\text { onboard } \\
\end{array}$ & $\begin{array}{l}10-100 \\
\text { Itrs }\end{array}$ & $\begin{array}{c}\$ 10,001- \\
100,000\end{array}$ \\
\hline 3 & Significant & $\begin{array}{c}\text { Injury } \\
\text { requiring } \\
\text { hospitali- } \\
\text { zation } \\
\end{array}$ & $\begin{array}{c}100-1000 \\
\text { Itrs }\end{array}$ & $\begin{array}{c}\$ 100,001- \\
1,000,000\end{array}$ \\
\hline 4 & Critical & $\begin{array}{c}\text { Single death } \\
\text { or } \\
\text { permanent } \\
\text { disability }\end{array}$ & $\begin{array}{c}1000 \text { - } \\
10000 \text { Itrs }\end{array}$ & $\begin{array}{c}\$ 1,000,001 \\
- \\
25,000,000\end{array}$ \\
\hline 5 & Catastrophic & $\begin{array}{l}\text { Multiple } \\
\text { deaths }\end{array}$ & $\begin{array}{l}\text { More than } \\
10000 \text { Itrs }\end{array}$ & \begin{tabular}{|c} 
More \\
than \\
$\$$ \\
$25,000,000$
\end{tabular} \\
\hline
\end{tabular}


The acceptable risk level, within the range 1-4 means that during an operation any additional safety measures are not necessary.

If the calculated risk is over 5, then the additional control actions must be considered in order to reduce the risk level. This means that active action has to be taken to control the risk in the workplace.

For example in the case of "Hot work on deck" operation risk assessment contains four hazards:

- fire - likelihood level $1 \mathrm{x}$ severity level $4=$ risk level 4

- crew injures - likelihood level 1 x severity level $4=$ risk level 4

- hull damage - likelihood level 1 x severity level $4=$ risk level 4

- cargo damage - likelihood level $1 \mathrm{x}$ severity level $4=$ risk level 4 .

Maximum risk level for "Hot work on deck" is 4. It means that risk is acceptable and work can be done. Following the procedures applied in ISM code by different operators for the example "Hot work on deck" the two different approaches to risk assessment can be compared.

Procedure 1 - the operator requires that the crew will send to the operator's office an e-mail with the basic information:

- what kind of hot work and where will be done,

- who will be involved and how long,

- what kind of safety equipment will be used.

When the duty safety manager accepts all conditions and risk assessment level feedback, the e-mail with permit to work is sent back to the ship,

Procedure 2 - risk assessment is carried out by Risk Assessment Team on board ship and if the risk level is acceptable the work could be done without any special work permit from the office.

The specific character of the hazardous operations carried out on board vessels is related to the level of uncertainty of the operational conditions. This uncertainty has to be considered with respect to the risk acceptance criteria using the multi layer risk matrix $[2,4]$.

In the onboard SMS systems the first layer is related to the risk level obtained due to the application of safety measures with respect to the particular check list.

The second layer is related to the risk level after the introduction of the additional risk control options, when the accepted risk level is exceeded.

\section{Merits and drawbacks of the approach applied in the development of accepted risk levels in SMS.}

In case of departure from the conditions provided in the check list, when the accepted risk level is exceeded, the successive layers of the risk matrix are considered by the ship operator. The additional risk reduction options are proposed or the operation is delayed until the new procedure is developed. 
The advantages of the presented approach are increase of safety culture, improvement of crew and shore personnel skills in methods of risk reduction, possibility of online introduction of improvements in safety management systems.

The main disadvantages are the complex data bases and variety of action schemes in emergency situations, used by the different shipowners. The crew members have to attend training practices and pass exams before their work onboard vessels.

In the situations not included in the manuals the Ship Master has to inform operator's office and wait for the new instructions. This results in the apparent transfer of responsibility from Ship Master to ship operator.

\section{Conclusions}

The simultaneous assessment of the risk level and application of the standard procedures facilitates decision making in emergency situations. However the accumulation of huge amount of information results in longer time of decision making process and the possibility of delay in response to the unexpected event. There are uncertainties in the determination of risk acceptance criteria related to the assumptions and simplifications assumed also the risk parameters determined by the distant elements in the event scenario in natural way have high uncertainty $[5,9,13]$. The risk acceptance criteria are used when the decision about acceptable risk is undertaken in a given context. They must be established before conducting a risk analysis [16]. The changes in technology, rules and guidelines, safety goals, methodology of analysis and operational methods are the reason the risk evaluation criteria used by IMO have to be updated along with the risk acceptance principles.

\section{References}

[1] Abramowicz Gerigk T.: Bezpieczeństwo manewrów krytycznych statków w systemie transportowym autostrady morskiej, Oficyna Wydawnicza Politechniki Warszawskiej, Warszawa 2012.

[2] Abramowicz-Gerigk T., Burciu Z., Kamiński P. Kryteria akceptowalności ryzyka $\mathrm{w}$ żegludze morskiej. Bezpieczeństwo i analiza ryzyka $\mathrm{w}$ transporcie.

Prace naukowe, Transport z. 96. Oficyna Wydawnicza Politechniki Warszawskiej, Warszawa 2013.

[3] Aven T., Vinnem J., Vollen E. Perspectives on Risk Acceptance Criteria and Management for Offshore Applications - Application to a Development Project. International Journal of Materials \& Structural Reliability Vol.4, No.1, March 2006, pp. 15-25

[4] Best Management Practices for Protection against Somalia Based Piracy Suggested Planning and Operational Practices for Ship Operators and Masters of Ships Transiting the High Risk Area Version 4, Witherby Publishing Group Ltd. Edinburgh, Scotland, UK, 2011.

[5] Borysiewicz M., Markowski A.: Kryteria akceptowalności ryzyka poważnych awarii przemysłowych. Centralny Instytut Ochrony Pracy - Państwowy Instytut Badawczy, Warszawa 2002. 
Practical aspects of risk acceptance criteria development Praktyczne aspekty określania kryteriów akceptacji ryzyka

[6] Burciu Z.: Niezawodność akcji ratowniczej w transporcie morskim. Oficyna Wydawnicza Politechnika Warszawska, Warszawa 2012.

[7] Energy Report Risk for striking impact to LNG carriers - Skangass LNG plant Skangass AS, DNV Report no: 2009-0089 Final, Rev 1, 2009.

[8] Gerigk M.: Kompleksowa metoda oceny bezpieczeństwa statku w stanie uszkodzonym z uwzględnieniem analizy ryzyka. Politechnika Gdańska. Monografie 101. Gdańsk 2010.

[9] Grabski F.: Stochastyczne modele awarii. V Sympozjum Bezpieczeństwa w transporcie Morskim. Iława 2009.

[10] Gucma S.: Inżynieria ruchu morskiego. Okrętownictwo i Żegluga, Gdańsk 2001.

[11] Guidelines on the Application of the IMO International Safety Management (ISM) Code Fourth Edition 2010 (ICS/ISF).

[12] Kodeks morski ustawa z dnia 18.09.2001. Dz.U. z 2009 nr 217 poz. 1689.

[13] Kristiansen S.: Maritime Transportation. Elsevier Butterworth-Heinemann, Oxford, UK 2005.

[14] Risk Management Procedure, RMS WHS Procedure: PN, Version: 2.0, Transport, Roads and Maritime Services, http://www.rms.nsw.gov.au/ doingbusinesswithus/downloads/contractor-ohs/02_00.pdf, 2012.

[15] Skjong, R. Regulatory framework. In: Papanikolaou, A. D. (Ed), Risk-Based Ship Design - Methods, Tools and Applications, Springer, Berlin, 2009, pp. 97-151.

[16] Vinnem J. E., Aven T. On the use of risk acceptance criteria in the offshore oil and gas industry. Reliability Engineering \& System Safety, Volume 90, Issue 1, October 2005, pp. 15-24.

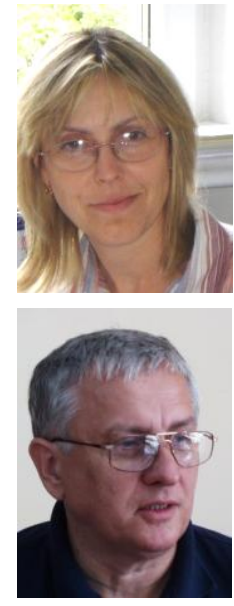

Dr hab. inz. Teresa Abramowicz -Gerigk, Akademia Morska w Gdyni (Gdynia Maritime University, Faculty of Navigation). Specialist in modelling of ship dynamics and safety of maritime transportation. Author or coauthor of more than 60 publications, both in Polish and English. Member and coordinator of national and international $R \& D$ projects.

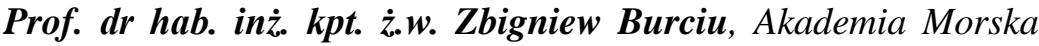
w Gdyni (Gdynia Maritime University, Faculty of Navigation). Specialist in modelling of safety and reliability of Search and Rescue operations and safety of maritime transportation. Author or coauthor of more than 80 publications, both in Polish and English. Coordinator of national and international $R \& D$ projects. Member of Scientific-Technical Board at Chief of the National Civil Defense.

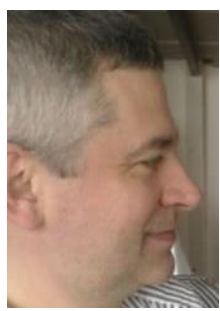

Mgr inz. kpt. ż. w. Piotr Kamiński, Akademia Morska w Gdyni (Gdynia Maritime University, Faculty of Navigation). Specialist in safety of maritime transportation. Author or coauthor of 4 publications, both in Polish and English. Member of national and international $R \& D$ projects. 